\title{
LABOUR MARKET EXPECTATIONS OF GENERATION Y
}

Linda Perkune ${ }^{1}$, MBA; Lasma Licite ${ }^{2}$, Dr.oec., associate professor

${ }_{1,2}$ Latvia University of Life Sciences and Technologies

\begin{abstract}
The replacement of each generation brings a major change in society because the employer must be able to adapt to what can be offered and what the required generation of representatives can offer. Generation $Y$ is a generation with birth years of 1982 through 2004. This generation is obsessed with technologies; they change their jobs often looking for better opportunities and seek the meaning of everything they do. In Latvia, Generation $\mathrm{Y}$ accounts for $23 \%$ of the total population and $32.1 \%$ of the total number of employed individuals. This indicates that this generation intensively enters the labour market and employers have to deal with the workplace expectations and values of Generation Y. The aim of the research is to examine the labour market expectations and values of Generation Y. To identify them, the authors conducted a survey of 308 Generation $Y$ students at Latvia University of Life Sciences and Technologies. The survey revealed that the key factors affecting the motivation of Generation $Y$ students in Latvia were regular remuneration and a pleasant and safe atmosphere. In the context of the role of a job, building up new knowledge and skills was also important, yet the fact that No explicit hierarchy of relationships existed at the enterprise was the determinant factor contributing to the sense of belonging. The workplace expectations of Generation $Y$ students were considerably affected by their field of studies chosen as well as employment status (employed/unemployed). However, all the students referred to the importance and meaning of the job done as an essential factor.
\end{abstract}

Key words: Millennials, Generation Y, expectations, labour market.

JEL code: J21, J82.

\section{Introduction}

As the amount of information increases, labour market requirements change - a few years ago the labour market situation required those entering the labour market to be highly qualified, have a lot of work experience, knowledge, skills and abilities to be ready to work from any place in the world 24 hours a day. At present, tremendous changes occur in the labour market because Generation $Y$ individuals enter the labour market and strengthen their positions, and their behaviour, expectations and values are extensively discussed in the labour market context (Johnson M. K., 2002; Lee C. S. et al., 2012). This generation has completely changed labour market rules, so potential employees can set their requirements rather than they have to adapt to the existing ones (Jekabsone G., 2018).

In view of a lack of the workforce in Latvia, it is important for entrepreneurs to adapt to the values and expectations of Generation Y. In 2017, according to the Central Statistical Bureau (CSB), Generation $Y$ in particular comprised $23 \%$ of the total population of Latvia; besides, this generation represented $32 \%$ of total employment, and the Figures are expected to increase because Generation Y, which made up $89 \%$ of total students in 2017, intensively joins the labour market.

The present research defines Generation $Y$ as those who were born in the period from 1982 to 2004 (Howe N., Strauss W., 1991). However, it has to be taken into consideration that the values and expectations of Generation $Y$ are considerably affected by the way they were brought up and their lifestyle and age stage. In 2018, Generation $Y$ individuals were aged 14-36, i.e. they represented a broad range of individuals.

In Latvia, Generation Y has been researched by L. Licite and L. Janmere (2017) who analysed the higher education expectations of Generation Y students as well as Z. Rubene (2018) who described Generation $Y$ from various aspects and examined the factors affecting the generation and trends in its development. The values and expectations of Generation $Y$ in the labour market context have

\footnotetext{
${ }^{1}$ Corresponding author. E-mail address: linda.perkune@Ilu.Iv

${ }^{2}$ Corresponding author. E-mail address: lasma.licite@Ilu.Iv
} 
been extensively researched by foreign scientists (Gursoy D. et al., 2013; Sherman R. O., 2005; Stewart J. S. et al., 2017). In Latvia, however, there is a lack of research studies on the labour market expectations of Generation $Y$ in particular.

Hypothesis: at the workplace, Generation $Y$ expects competitive remuneration and a motivational working environment. The research aim is to examine the labour market expectations and values of Generation Y. To achieve the aim, the following specific research tasks were set: 1 ) to describe Generation $Y$ in the labour market context in Latvia; 2) to conduct a survey to find out the expectations of Generation $Y$ students in labour market.

To achieve the aim and perform the tasks, the research employed several methods. The monographic and descriptive methods were used to make a theoretical discussion and interpret the research results based on scientific findings and theories on Generation $Y$ and its labour market expectations. Analysis and synthesis were employed to examine problem elements and identify regularities. Induction was used to make scientific assumptions from individual elements or facts and identify causal associations. Deduction was used for logically systemising and explaining empirical data. To identify the labour market expectations of Generation Y, the authors surveyed 308 students of Latvia University of Life Sciences and Technologies. The survey was conducted from September to November 2018. The target population was Generation $Y$ students aged 18-36 (the average age of the respondents was 21.5 years). The students were random sampled among those studying biosciences ( 74 students), engineering (118 students) and social sciences (116 students); the sample included both working and non-working students. A statistical analysis method - contingency analysis was applied to analyse the values and expectations of the Generation Y students.

\section{Characteristics of Generation $\mathbf{Y}$ in the context of the labour market of Latvia}

The concept of generations is a way how to describe events and trends occurring in various periods, analyse data as well as explain on-going processes from the perspective of human resources. Nowadays, the population could divided into five generations (Cort W. R. et al., 2018). According to the scientific literature, Generation $Y$ has the following general characteristics: an ability to perform a number of tasks simultaneously, No acceptance of a hierarchy of relationships as well as selfconfidence (Monaco M., Martin M., 2007). Generation Y wishes to do a job with feedback; they have a wish to be leaders and achieve everything fast. They are not ready to work as hard as previous generations did, as their priority is their personal lives and hobbies (Srinivasan V., 2012).

A research study done by Wong I. A. et al. (2017) revealed that at the job, work motivation, work meaning and the sense of belonging were three most important factors for Generation $Y$ (Fig. 1).

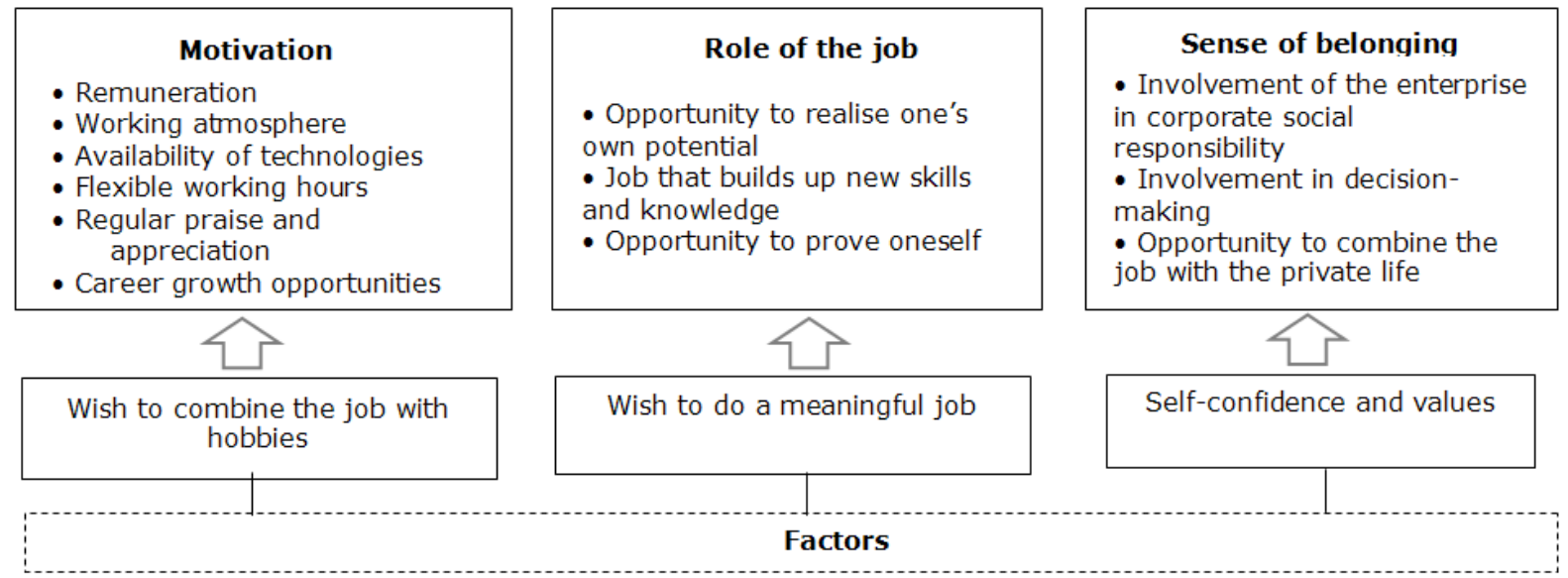

Source: authors' construction based on Wong I. A. et al., 2017 
Generation $Y$ individuals usually rarely stay at one job for more than a couple of years (Videjais vecums un..., [s.a.]). This means that it is important for employers to be aware of the labour market expectations of Generation $Y$ in order to create jobs that employees want to keep for a long time. This fact is important because in 2017, according to the CSB, out of 1934379 residents of Latvia, $23 \%$ were aged 14-36 (totally 451343 Generation Y individuals) (Fig. 2) (Videjais vecums un.., [s.a.]). It means that Generation $Y$ is the second largest generation behind Generation $X$, which gradually replaces Generation X in the labour market.

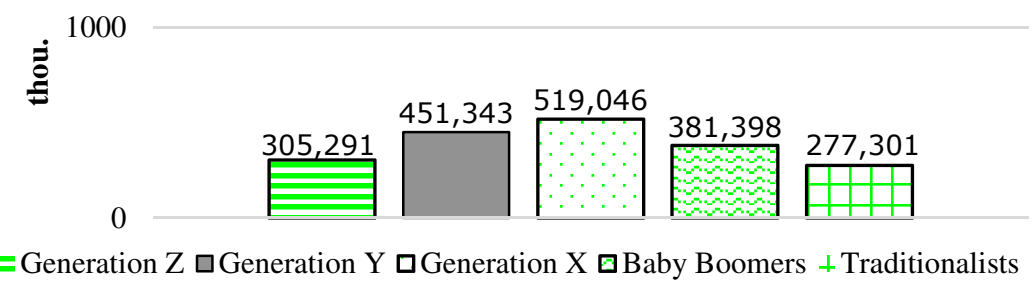

Source: authors' construction based on Central Statistical Bureau data, 2017

Fig. 2. Breakdown of the population by generation in Latvia in 2017, thou.

It is important not only break the population down by generation but also analyse employment and education indicators by generation. As shown in Table 1, in 2017 in Latvia the economically active population (Generation $Y$ ) constituted $31.5 \%$ of the total active population (Ekonomiski aktivie iedzivotaji..., [s.a.]). Of the total population, 861.9 thou. were employed, of which 277 thou. or $32 \%$ represented Generation Y. Generation Y comprised 37 \% of total unemployment (Bezdarbnieki pa vecuma..., [s.a.]). This allows concluding that Generation $Y$ represented a significant proportion of total unemployment; besides, the proportion continues increasing. The calculations of employment were performed in accordance with Section 37 of the Labour Law (in force since 1 June 2020) that stipulates that minors aged 15 and older may be permanently employed, i.e. persons belonging to Generation $\mathrm{Y}$ and aged 14 are excluded.

Table 1

Breakdown of the Generation $Y$ workforce in Latvia in 2017, thou.

\begin{tabular}{|l|c|c|c|}
\hline \multicolumn{1}{|c|}{ Status } & $\begin{array}{c}\text { Generation Y, thou. } \\
\text { people }\end{array}$ & $\begin{array}{c}\text { Total, thou. } \\
\text { people }\end{array}$ & $\begin{array}{c}\text { Proportion of Generation } \\
\text { Y in total population, \% }\end{array}$ \\
\hline $\begin{array}{l}\text { Economically active } \\
\text { population }\end{array}$ & 308.5 & 980.3 & 31.5 \\
\hline Employed & 277.0 & 861.9 & 32.1 \\
\hline Unemployed & 31.6 & 85.4 & 37.0 \\
\hline
\end{tabular}

Source: authors' construction based on Central Statistical Bureau data, 2017

Many employers pointed out that the largest problem related to Generation $Y$ was that they were not reliable, as this generation individuals often changed jobs and did not stay at the job for a long time (Rubene Z., 2018). However, Section 106 of the Constitution of the Republic of Latvia (in force since 1922) states that "everyone has the right to freely choose their employment and workplace according to their abilities and qualifications".

To save enterprise resources, employers often choose not to remunerate their employees being on study leave, which is allowed by Section 157 of the Labour Low: "An employee, who without discontinuing work, studies at an educational institution of any type, in accordance with a collective agreement or an employment contract shall be granted study leave with or without retention of work remuneration. If a piecework salary has been specified for the employee, study leave shall be granted disbursing average earnings or not disbursing it. An employee shall be granted a study leave of 20 working days for the taking of a State examination or the preparation and defence of a diploma paper with or without retaining the work remuneration. If a piecework salary has been specified for the 
employee, a study leave shall be granted with or without disbursing the average earnings" (Labour Law, 2002). Despite the fact that Paragraph 1 of Section 29 of the Labour Law stipulates that "differential treatment based on the gender of an employee is prohibited when establishing employment legal relationships, as well as during the period of existence of employment legal relationships, in particular when promoting an employee, determining working conditions, work remuneration or occupational training or raising of qualifications, as well as when giving notice of termination of an employment contract" and Paragraph 9 of this section adds that "the provisions of Section 29, insofar as they are not in conflict with the essence of the relevant right, shall also apply to the prohibition of differential treatment based on age (...)", a potential employer may choose to hire another applicant on the pretext that he/she has larger experience (Labour Law, 2002).

Overall, however, an analysis of the legal framework of the Republic of Latvia allows concluding that Generation $Y$ youth are protected by the law, for instance, Section 32 of the Labour Law prescribes: „It is prohibited to indicate age limitations in a job advertisement except in cases where, in accordance with the law, persons of a certain age may not perform relevant work" (Labour Law, 2002).

\section{Labour market expectations of Generation $\mathbf{Y}$}

To examine the expectations and values of Generation $Y$ at the workplace, the authors conducted a survey. The survey revealed that in planning future careers, financial motivation factors were important or very important to Generation $Y$ students. The key financial motivation factor was steady and regular remuneration that was also adequate to the market situation. Of the total respondents, $94 \%$ considered steady and regular remuneration a very important factor, while remuneration adequate to the market situation was important to $76 \%$ (Fig. 3).

Availability of the latest technologies was important or very important in the choice of a potential job for $62 \%$ of the respondents. Since technologies progress fast, it is understandable that a potential employee wishes that the employer keeps up with innovations, providing an interactive environment and all the amenities ensured by technological progress. It has to be noted that engineering students in particular ( $88 \%$ of the total engineering respondents) were those who rated this factor as "very important" or "important”, which could be explained by the fact that engineering is based on technologic progress that considerably contributes to developing new products or enhancing production processes.

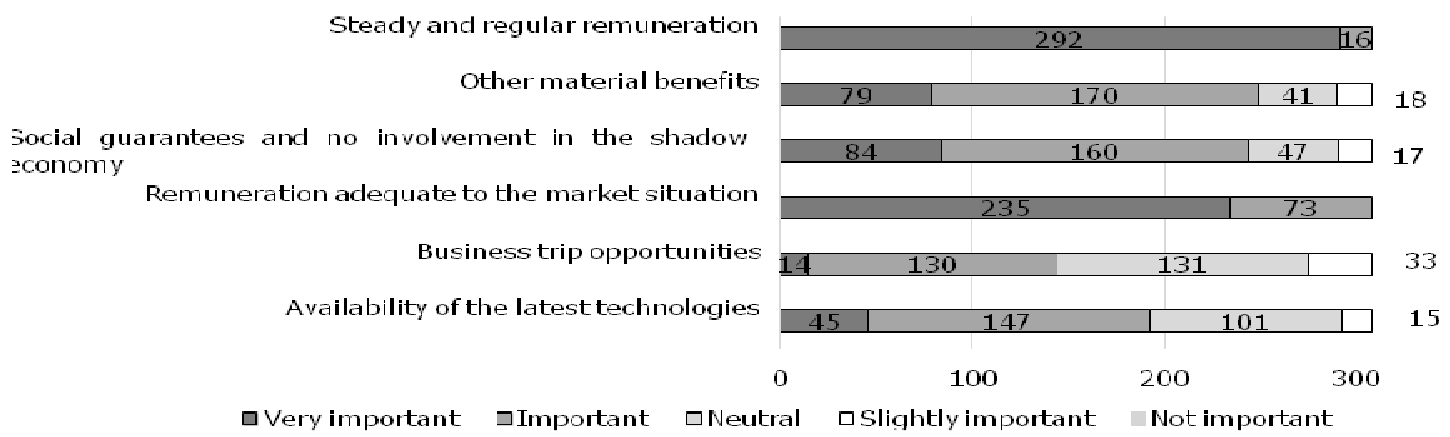

Source: authors' survey.

Fig. 3. Respondents' expectations of financial remuneration at the job

The research examined non-financial motivation factors such as flexible working hours, an opportunity to work from home, an accepTable workload, non-financial bonuses and career opportunities (Fig. 4). The survey revealed that most of the respondents were unanimous in wishing 
a pleasant and safe atmosphere at their future workplaces - $98 \%$ rated this factor as "very important" or "important" and only 3 \% or 10 students rated it as "neural”. Despite the fact that a pleasant and safe atmosphere was wished by almost all the respondents, other non-financial bonuses available at the job such as a fitness room or a rest area were rated as "important" or "very important" by only $36 \%$. Most of the respondents, $64 \%$, rated them as "neutral". This might be explained by the wish of Generation $Y$ to use the workplace only as a platform for working rather than spending one's own free time, preferring resting during a desired free time. It has to be stressed that $52 \%$ of the respondents who gave a "neutral" or "slightly important" rating had employment relationships when they were surveyed.

Non-work activities (excursions, festivities)

$$
\text { Colleagues are peers }
$$

No hierarchy at the enterprise

Regular praise and appreciation

Prestige of the enterprise

Involvement of the enterprise in corporate social responsibility

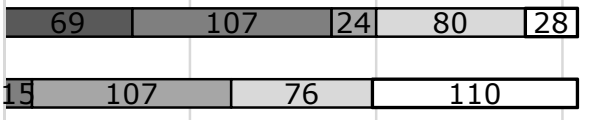

\begin{tabular}{|l|l|l|}
\hline 74 & 202 & 32 \\
\hline
\end{tabular}

\begin{tabular}{|l|l|l|l|}
\hline 96 & 145 & $52 \quad 15$ \\
\hline
\end{tabular}

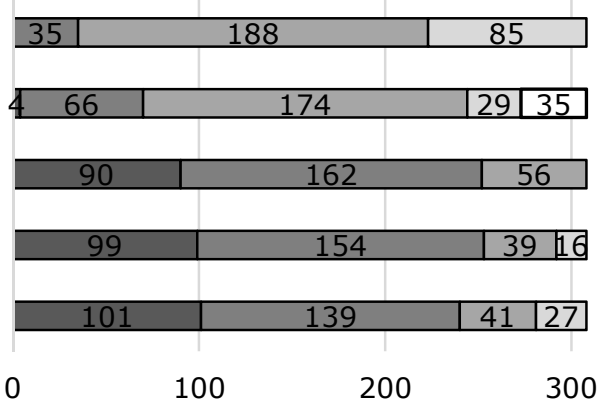

400

口Very important aImportant aNeutral aSlightly important aNot important

\section{Source: authors' survey.}

\section{Fig. 4. Respondents' expectations of non-financial remuneration at the job}

A contingency analysis proved that at a confidence level of $95 \%$, there was a causal association between the factor "rest area, a fitness room or other non-financial bonuses" and student employment status (employed, unemployed), namely, non-financial bonuses were less important to the students who had employment relationships than to non-working ones. This could be explained by the fact that often in daily life, employees have not considered such bonuses or, if the bonuses were available, they would not be important due to the specifics of the job or due to the work schedule.

An opportunity to work from home was rated as "very important" by $54 \%$ of the respondents, while $33 \%$ rated it as "neutral" or "slightly important" (73\% were working students), which could indicate that the working environment was favourable for them. Even though an opportunity to work from home was appreciated by slightly more than half of the respondents, flexible working hours were rated as "very important" or "important" by $77 \%$, and none of them rated it as "slightly important" or "unimportant". The importance of this factor could be explained by the wish of Generation $Y$ to combine their jobs with their hobbies and private lives (Cort W. R. et al., 2018).

An analysis of the respondents' ratings of the factors contributing to the sense of belonging at the workplace showed that non-work activities and an opportunity to combine the job with hobbies were important. Non-work activities (e.g. excursions and festivities celebrated collectively) were important to $35 \%$ of the respondents, yet a large number of the respondents $(26 \%)$ rated them as "slightly important". It has to be noted that $96 \%$ of the respondents who gave "slightly important" ratings 
did not have employment relationships, while those who worked when the survey was carried out mainly gave "very important” or "important” ratings. This might be explained by the fact that generation $Y$ individuals who worked appreciated the events held by their employers.

More than half of the respondents ( $57 \%$ ) rated the importance of involvement of the enterprise in corporate social responsibility to a potential employee as "neutral". Only $1.3 \%$ rated it as "very important". The high percentage of "neutral" ratings could indicate the fact that the respondents were uninformed or unaware of corporate social responsibility. This means that enterprises should give more information about their social activities to make youth and potential employees aware of their engagement in benefiting the society. To identify whether there is an association between the students' attitude to involvement of the enterprise in corporate social responsibility and the field of studies chosen by the students, the authors did a contingency analysis that proved that at a confidence level of $95 \%$, there was a causal association between the factor "involvement of the enterprise in corporate social responsibility" and the fields of studies chosen by the students. The survey revealed that involvement of the enterprise in corporate social responsibility was more important to bioscience students than to other science students.

It was very important or important for $82 \%$ of the respondents whether the potential employer supported travels and participation in conferences and professionalism courses. Such a rating might be explained by the wish of Generation $Y$ individuals to persistently develop themselves as well as the wish of Generation $Y$ youth to travel and seek for new challenges.

It is very important for Generation $Y$ not to have a strong hierarchy of relationships between management and employees at the enterprise, and the survey revealed that the lack of a hierarchy was a very important or important factor for $90 \%$ of the respondents. Besides, those who had employment relationships considered this fact to be very important, as $65 \%$ of them rated it as "very important", which could be explained by either their dissatisfaction with their jobs and the wish to work at an enterprise with friendly relationships between the employer and the employee or an opposite situation - such relationships already existed at their enterprises.

In contrast to the findings given by theory, the survey revealed that the Generation $Y$ individuals rated regular praise as "neutral”, and only $31 \%$ of the respondents indicated they wished to regularly receive appreciation for well-done work. This could be explained by the mentality or traits and viewpoint of each individual, given the fact that Latvians are considered to be introverted individuals who do not always express their emotions (Ro C., 2018).

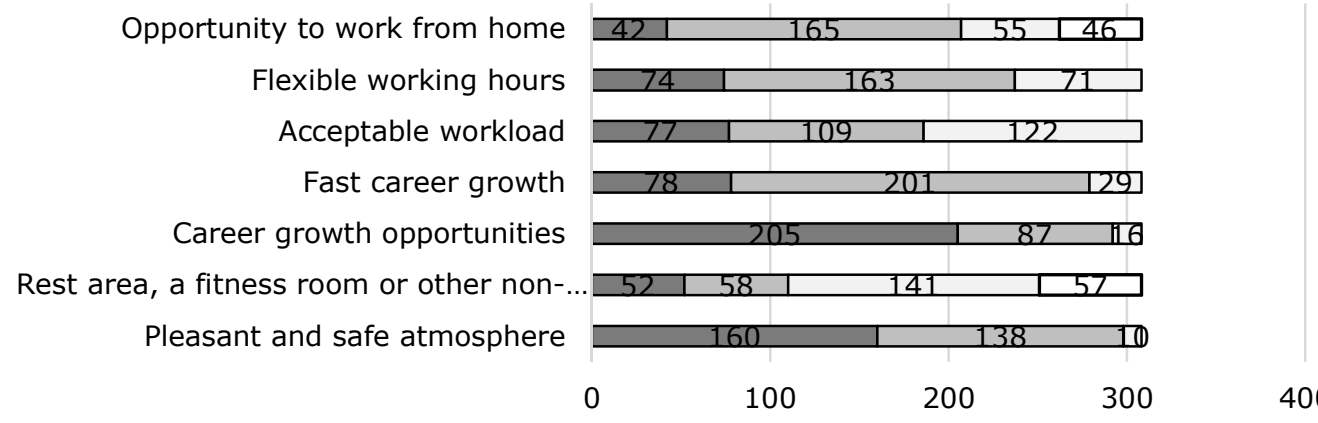

口Very important $\square$ Important $\square$ Neutral $\square$ Slightly important $₫$ Not important

Source: authors' survey

Fig. 5. Generation $\mathbf{Y}$ ratings of the factors contributing to the sense of belonging to $\mathbf{a}$ job

An analysis of the factors affecting the role of a job showed that it was important for Generation $Y$ to do a meaningful job that was in line with their interests. The only factor that was rated as 
"neutral" by most of the respondents (55 \%) was the wish to have a job full of passion and challenges (exactly half of them were working students, which could mean their current jobs were monotonous).

An opportunity to do a job that is important for society was important to $51 \%$ of the respondents, while $8.4 \%$ considered it slightly important or unimportant. Even though only slightly more than half of the respondents wished to do a job that is important for society, a meaningful job making a lasting contribution to the enterprise was very important or important for $79 \%$. The contingency analysis proved that at a confidence level of $95 \%$, one could not reject an assumption that doing a meaningful job was important to Generation $Y$ students regardless of their fields of studies and employment status.

The aspects of high self-awareness of Generation $Y$ described in the scientific literature were reflected in the respondents' ratings of the role of a job, namely, it was important for $94 \%$ of them to do a job they were interested it, $96 \%$ wished to feel important at the job; it was very important for $45 \%$ to have a job position being considered prestigious in society, while $53 \%$ wished to have a job where they could manage others and it was very important or important for $98 \%$ to enhance their professionalism at the job. The ratings pointed to the above-described characteristics of Generation $Y$ - their wish to feel important, persistently develop themselves as well as the fact that a considerable proportion of them wished to start up their own businesses, which was evidenced by the high proportion of the respondents wishing to manage others (only $10 \%$ indicated it was unimportant for them to hold a job position allowing managing others).

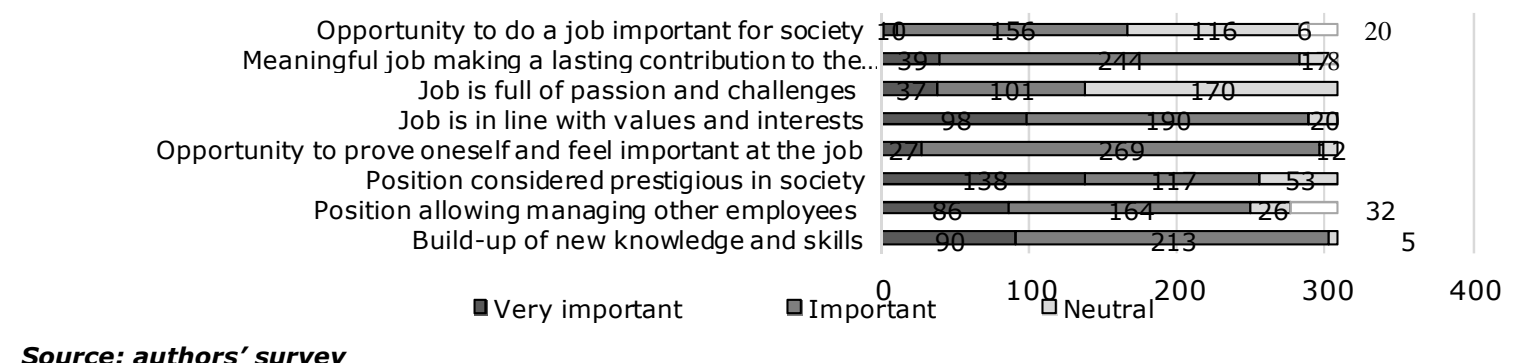

Source: authors' survey

Fig. 6. Generation $\mathbf{Y}$ ratings of the role of employment

One can conclude that the labour market expectations of Generation $Y$ are quite ambitions; besides, the expectations are affected by the field of studies and employment status.

\section{Conclusions and proposals}

1) In Latvia, Generation $Y$ accounted for $23 \%$ of the total population, $31.5 \%$ of the total economically active population, $32.1 \%$ of the total number of employed individuals and $37.0 \%$ of the total number of unemployed individuals. This indicates that this generation intensively enters the labour market and employers have to deal with the expectations and values of Generation $Y$ at the workplace.

2) In Latvia, the key factors affecting the motivation of Generation Y students in Latvia were steady, regular remuneration and a pleasant and safe atmosphere. Building up new knowledge and skills was the most important values in relation to the role of a job, yet the determinant factor contributing to the sense of belonging was a lack of a hierarchy of relationships at the enterprise.

3) The workplace expectations of Generation $Y$ students were considerably affected by their fields of studies chosen as well as employment status (employed/unemployed). Involvement of the enterprise in corporate social responsibility was more important to bioscience students, engineering students preferred availability of technologies, while non-financial bonuses (a fitness room and a rest area) were slightly important to working students. A meaningful and important 
job was important to Generation Y students regardless of their fields of studies and employment status.

\section{Bibliography}

1. Bezdarbnieki pa vecuma grupam un pec dzimuma (Unemployed by Age Group and Sex). Retrieved: http://data1.csb.gov.Iv/pxweb/lv/sociala/sociala_nodarb__bezdarbs_ikgad/NBG250.px/?rxid=a39c3f49e95e-43e7-b4f0-dce111b48ba1. Access: 08.02.2019.

2. Cort, W. R., Rachel, S. R., Hannes, Z. (2018). Leadership and Generations at Work: A Critical Review. The Leadership Quarterly, No. 29, pp. 44-57.

3. Ekonomiski aktivie iedzivotaji pa vecuma grupam un pec dzimuma (Active Population by Age Group and Sex) Retrieved: http://data1.csb.gov.Iv/pxweb/lv/sociala/sociala_nodarb_aktivitate_ikgad/NBG060.px/?rxid=a39c3f49e95e-43e7-b4f0-dce111b48ba1. Access: 08.02.2019.

4. Gursoy, D., Geng - Qing Chi, C., Karadag, E. (2013). Generational Differences in Work Values and Attitude among Frontline and Service Contact Employees. International Journal of Hospitality Management, No. 32, pp. 40-48.

5. Howe, N., Strauss, W. (1991). Generations: The History of America's Future, 1584 to 2069. New York: Willian Morrow and Company, Inc. p. 544.

6. Jekabsone, G. (2018). Ka cinities ar bezdarbu darbinieku trukuma apstaklos (How to Cope with Unemployment in the Absence of Employees). Retrieved: https://www.ficil.Iv/blogs/ka-cinities-ar-bezdarbudarbinieku-trukuma-apstaklos/apstaklos/. Access: 08.02.2019.

7. Johnson, M. K. (2002). Social Origins, Adolescent Experiences, and Work Value Trajectories during the Transition to Adulthood. Social Forces, Volume 80, pp. 1307-1341.

8. Labour Law (2002). Retrieved: https://likumi.lv/doc.php?id=26019. Access: 08.02.2019.

9. Lee, C. S., Hung, D. K. M., Ling, T. C. (2012). Work Values of Generation Y Preservice Teachers in Malaysia. Procedia - Social and Behavioral Sciences, Volume 65, pp. 704-710.

10. Licite, L., Janmere, L. (2017). Millennial Student Expectations towards Higher Education in Latvia. In: Engineering for Rural Development, No. 16. Jelgava: LLU, pp. 1440-1449.

11. Monaco, M., Martin, M. (2007). The Millennial Student: A New Generation of Learners. Athletic Training Education Journal, Volume 2, pp. 42-46.

12. Rubene, Z. (2018). Profesore: vai millennium paaudzei ir svariga izglitiba (Professor: Is education important for the millennium generation?). Latvijas Avize, February 19. Retrieved: http://www.la.Iv/profesore-vaimillenium-paaudzei-ir-svariga-izglitiba. Access: 08.02.2019.

13. Ro, C. (2018). Latvia: Europe's Nation of Introverts. Retrieved: http://www.bbc.com/travel/story/20180611-latviaeuropes-nation-of-introverts. Access: 08.02.2019.

14.Sherman, R. O. (2005). Growing our Future Leaders. American Nurse, Volume 2, Issue 1, pp. 125-132

15. Stewart, J. S., Oliver, E. G., Cravens, K. S., Oishi, S. (2017). Managing Millennials: Embracing Generational Differences. Business Horizons, Volume 60, pp. 45-54.

16. Srinivasan, V. (2012). Multi Generations in the Workforce: Building Collaboration. IIMB Management Review, Volume 24, pp. 48-66.

17. Videjais vecums un iedzivotaju skaits pec vecuma un dzimuma statiskajos regionos un republikas pilsetas gada sakuma (Average Age and Number of Population in Statistical Regions and Cities under State Jurisdiction by Age and Gender; at the Beginning of the Year). Retrieved: https://data1.csb.gov.Iv/pxweb/lv/iedz/iedz_iedzrakst/IRG030.px/?rxid=5ab25eea-86df-45f1-ada2bd7707c55eb7. Access: 08.02.2019.

18. Wong, I. A., Wan, Y. K. P., Gao, J. H. (2017). How to Attract and Retain Generation Y Employees? An Exploration of Career Choice and the Meaning of Work. Tourism Management Perspectives, No. 23, pp. 140150. 